\title{
Mampukah Komite Audit Membantu CEO Menekan Biaya Audit ?
}

\author{
Edi Sukarmanto \\ Universitas Islam Bandung \\ edio6sukarmanto@gmail.com
}

\author{
Tityan Sukma Dewi \\ Universitas Islam Bandung \\ tityansukmadewi582@gmail.com
}

\author{
Gifani Marsianda Anindita \\ Universitas Islam Bandung \\ Gmarsianda@gmail.com
}

\begin{abstract}
Abstrak
Penelitian ini bertujuan menguji kemampuan CEO dan audit komite berkeahlian akuntansi dan keuangan dalam mengurangi biaya audit, dan komite audit mampu membantu CEO dalam mengurangi biaya audit. Dalam melakukan pemeriksaan pada tujuan penelitian, peneliti menggunakan analisis regresi linier berganda dan menggunakan data 75 perusahaan manufaktur yang tercatat di Bursa Efek Indonesia untuk rentang pengamatan 2010 - 2016 atau 525 observasi. Hasil pengujian menunjukkan bahwa CEO dengan keahlian akuntansi dan keuangan dapat menekan biaya audit yang dibayarkan. Di sampint itu juga, audit komite berkeahlian akuntansi dan keuangan juga dapat menurunkan biaya audit. Dengan demikian, audit komite dapat membantu CEO dalam mengurangi biaya audit. Studi ini memberikan implikasi bagi perusahaan untuk memperhatikan faktor keahlian akuntansi dan keuangan dalam menentukan CEO dan anggota audit komite. Hal ini tidak hanya berdampak pada penentuan biaya audit, tetapi juga dapat meningkatkan kemampuan memahami proses penyajian informasi keuangan sehingga dapat menciptakan laporan keuangan yang berkualitas.
\end{abstract}

Kata Kunci: Keahlian Akuntansi dan Keuangan, Chief Executive Officer, Komite Audit 


\section{Pendahuluan}

Sejak terjadinya kegagalan akuntansi pasca periode Sarbanes-Oxley (SOX), banyak pihak memberikan perhatian yang lebih pada integritas manajemen perusahaan dan auditor eksternal. Kondisi ini semakin diperburuk dengan adanya resesi ekonomi yang mengakibatkan banyak perusahaan mengalami kesulitas keuangan. Hal ini memberikan cerminan bahwa pengelolaan keuangan dilakukan dengan kualitas yang rendah. Untuk mendapatkan pengelolalaan proses akuntansi yang lebih baik, banyak perusahaan mencoba menggunakan Chief Executive Officer (CEO) yang berlatar belakang akuntansi dan keuangan. Di Indonesia, keberadaan CEO yang berkeahlian akuntansi dan keuangan di dalam perusahaan belum banyak menjadi fokus utama. Walaupun demikian, dari data yang diperoleh dari pasar modal Indonesia, keberadaan CEO yang berkeahlian akuntansi dan keuangan telah mengalami sedikit peningkatan. Meningkatnya penggunaan CEO berkeahlian akuntansi dan keuangan karena dianggap akan mempunyai kemampuan yang lebih baik dalam mengelola sumber-sumber daya keuangan dan mampu menggunakan sumber-sumber tersebut lebih produktif, sehingga akan mengurangi kemungkinan terjadinya risiko kegagalan (Custodio dan Metzger, 2014). Di samping itu juga, keberadaan CEO yang berkeahlian akuntansi dan keuangan akan memberikan dampak terhadap kemampuan mereka dalam memahami kebijakan-kebijakan keuangan dan proses penyajian laporan keuangan, sehingga memungkinkan perusahaan mampu meningkatkan kualitas laba yang dihasilkan (Cao dan Narayanamoorthy, 2014).

Tidak berbeda halnya dengan CEO, anggota komite berkeahlian akuntansi dan keuangan juga memberikan peran dalam menekan terjadinya risiko bisnis. Dibentuknya komite audit, secara independen diharapkan akan membantu pihak manajemen melakukan pengawasan pelaksanaan operasional perusahaan, khususnya dalam mengawasi kebijakan-kebijakan akuntansi dan alat-alat pengendalian perusahaan agar laporan keuangan lebih berkualitas. Keberadaan komite audit yang anggotanya berkeahlian akuntansi maupun keuangan dapat meningkatan kemampuan komite audit dalam menerapkan fungsi pemantauan maupun pengawasan. Di samping itu juga, dengan dimilikinya keahlian tersebut diharapkan dapat menurunkan tingkat kelemahan pengendalian intern (Krishnan, 2005) dan mencegah kemungkinan terjadinya manajemen laba (Badolato et al, 2014). Menurunnya tingkat kelemahan pengendalian intern tersebut tentu saja akan memberikan dampak terhadap tingkat risiko yang 
akan dihadapi perusahaan. Dalam audit, tingkat risiko perusahaan akan berdampak pada area yang akan menjadi titik fokus auditor dalam melakukan pelaksanaan pemeriksaan. Semakin rendah tingkat kelemahan pengendalian intern perusahaan, akan semakin sedikit juga area yang menjadi perhatian auditor. Hal ini akan berdampak pada semakin sedikitnya pengujian-pengujian yang dilakukan dan pada akhirnya akan menekan biaya audit.

Hal menarik lain yang muncul dari keberadaan CEO berkeahlian akuntansi dan keuangan adalah memungkinkan CEO akan lebih agresif dalam melakukan praktik-praktik manajemen laba (Gul et al, 2003). CEO berkeahlian akuntansi dan keuangan dianggap mempunyai tingkat kemampuan yang lebih tinggi dalam mendapatkan celah-celah kelemahan kebijakan akuntansi dan pengendalian intern. Hal ini akan memberikan dampak terhadap buruknya kualitas laporan keuangan sehingga akan meningkatkan risiko bisnis perusahaan. Hal serupa dapat pula terjadi pada komite audit yang mempunyai anggota berkeahlian akuntansi. Tingkat pemahaman yang lebih baik dari komite audit berkeahlian akuntansi dan keuangan terhadap tingkat risiko yang akan dihadapi akan meminta kepada auditor untuk memperluas area yang menjadi fokus audit dan menyarankan kepada manajemen untuk memanfaatkan auditor eksternal bereputasi tinggi. Hal ini akan berdampak terhadap meningkatnya biaya audit.

Kontroversi ini tentu saja akan menarik untuk dilakukan penelitian lebih lanjut agar dapat mendapatkan jawaban apakan kehadiran CEO dan komite audit berkeahlian akuntansi dan keuangan akan mampu menekan biaya audit yang tinggi. Diharapkan dengan dilakukannya penelitian dapat memberikan bukti awal tentang keterkaitan tersebut.

\section{Landasan Teori dan Pengembangan Hipotesis}

\subsection{CEO Berkeahlian Akuntansi dan Keuangan}

Kehadiran Chief Executive Officer (CEO) dalam meningkatkan kinerja perusahaan telah memberikan banyak perdebatan bagi berbagai pihak. Banyak pihak berpendapat bahwa keberhasilan suatu perusahaan sangat ditentukan oleh faktor terciptanya produk-produk yang berkualitas dan kemampuan dalam mempertahankan keberlanjutan hidup perusahaan, tidak disebabkan oleh kemampuan CEO (Hannan dan Freeman, 1977). Pendapat lain menyatakan bahwa keberhasilan suatu perusahaan merupakan perwujudan dari kontribusi yang diberikan oleh keandalan CEO dalam mengelola perusahaan (Hayes dan Schaefer, 2000). Lebih lanjut dikemukakan oleh Coff (2002) bahwa keandalan tersebut didukung oleh pengetahuan dan kemampuan yang dimiliki oleh CEO. Lebih spesifik Bhagat et al (2010) 
menyatakan dengan pendidikan dan pengalaman akan memberikan kontribusi besar dalam meningkatkan kemampuan seseorang dalam bekerja. Pendidikan dan pengalaman akan mengasah kemampuan dan membentuk pola pikir seseorang dalam memahami konsep teknis dan non teknis yang terdapat dalam pekerjaan.

Penelitian sebelumnya menemukan latar belakang pendidikan dan pengalaman pekerjaan membuat para manajer bekerja lebih efektif dalam memecahkan masalah-masalah yang ada dalam perusahaan (Koyuncu et al, 2010). Boyd et al (2010) juga menemukan CEO dengan latar belakang pendidikan dan pengalaman pemasaran menunjukkan kemampuan serta pemahaman yang lebih baik, sehingga lebih mampu menerapkan kebijakan pemasaran yang diterapkan pada perusahaannya. Dalam bidang akuntansi, beberapa penelitian menunjukkan bahwa CEO yang memiliki latar akuntansi dan keuangan mampu menekan biaya-biaya, mempunyai kemampuan yang lebih baik dalam memahami kinerja pasar modal, dan kurang sensitif terhadap guncangan arus kas (Custodio dan Metzger, 2014). Hal ini menyiratkan bahwa CEO akan lebih mampu memahami kebijakan-kebijakan keuangan sehingga lebih mampu mengawasi penyajian laporan keuangan. Oleh sebab itu, CEO akan lebih konservatif dan berakibat pada meningkatnya kualitas laporan keuangan yang dihasilkan. Pada sisi berbeda, tidak jarang semakin tingginya keahlian akuntansi dan keuangan yang dimiliki CEO dapat meningkatkan rasa percaya diri yang tinggi sehingga CEO akan lebih agresif dalam menyajikan laporan keuangan, sehingga dapat meningkatkan praktik manajemen laba yang tersaji dalam laporan keuangan (Badolato et al, 2010).

\subsection{Keahlian Akuntansi Dan Keuangan Komite Audit}

Secara umum komite audit diartikan sebagai sekumpulan individu yang dipilih dan dibentuk Dewan Komisaris untuk membantu pelaksanaan fungsi manejemen perusahaan serta membantu auditor melakukan pemeriksaan terhadap laporan keuangan. Dalam hal ini komite audit hendaknya tidak melibatkan diri dalam kegiatan operasional perusahaan. Secara spesifik, peran dan fungsi tersebut berguna untuk memantau proses pelaporan keuangan sehingga diharapkan mampu menekan sifat oportunistik manajemen. Peran ini mencerminkan adanya prinsip teori keagenan dan kebutuhan untuk memantau manajer untuk mengurangi kemampuan manajemen melakukan perilaku manajemen laba (Fama dan Jensen, 1983 Beasley et al., 2009). Lebih lanjut dikemukan oleh Abbot et al (2003), selain bertanggungjawab dalam pelaksanaan ketaatan hukum, anggaran dasar dan anggaran rumah tangga perusahaan, komite audit juga bertanggungjawab terhadap pelaksanaan pengendalian intern, kebijakan akuntansi, serta penyajian dan pengungkapan pelaporan keuangan secara akurat dan transparan. Oleh sebab itu, keahlian akuntansi dan keuangan merupakan salah satu syarat dalam keanggotaan suatu komite audit (Otoritas Jasa Keuangan, 2015).

ISSN : 1693-0164 | e-ISSN : 2581-074X 
Didorong oleh basis pengetahuan dan pengalaman tersebut, komite audit diharapkan dapat meningkatkan kemampuan pemantauan yang lebih baik. Krishnan (2005) melaporan dalam penelitiannya bahwa menurunnya tingkat kelemahan pengendalian intern sangat terkait dengan keahlian akuntansi komite audit. Penelitian lain menunjukkan bahwa menurunnya tingkat penyimpangan dalam perusahaan sangat dipengaruhi oleh keahlian akuntansi dan keuangan komite audit (Dhaliwal, Naiker, dan Navissi, 2010; Badolato, Danelson, dan Ege, 2014). Dengan keahlian yang mereka miliki, anggota komite audit dapat menilai kewajaran penjelasan yang disampaikan pihak manajemen, khususnya dalam mendeteksi sifat perselisihan manajemen dengan eksternal auditor (Krishnan, et.al., 2008). Dikemukakan oleh Agrawal dan Chadha (2005), ketika komite audit bertindak secara independen dan mempunyai keahlian dalam bidang keuangan, mempunyai kemampuan yang lebih baik dalam menurunkan kemungkinan terjadinya penyajian kembali suatu laporan keuangan. Temuan ini konsisten dengan gagasan bahwa independensi dan keahlian akuntansi yang terdapat dalam komite audit dianggap lebih mampu melakukan pengawasan yang ketat terhadap pelaporan keuangan. Hal ini menyiratkan bahwa tingginya kualitas pengawasan sangat berhubungan dengan keahlian akuntansi keuangan.

\subsection{Biaya Audit}

Penggunaan jasa auditor pada suatu perusahaan akan menimbulkan konsekuensi biaya yang harus dibayarkan kepada auditor. Biaya tersebut sebagai imbalan dari pekerjaan pemeriksaan terhadap laporan keuangan atau umumnya disebut biaya audit (audit fee). Besarnya biaya audit adalah suatu fungsi dari pemeriksaan terhadap klien dan risiko bisnis yang mungkin terjadi pada perusahaan (Hay et al, 2006). Pada kegiatan audit, auditor perlu melakukan pemahaman terhadap lingkungan bisnis dan industri perusahaan untuk mendapatkan gambaran tentang risiko bisnis, kompleksitas dari jasa yang diberikan, serta kemungkinan diperlukannya keahlian tertentu. Rendahnya pengetahuan maupun pemahaman auditor tentang lingkungan usaha maupun industri klien ditakutkan akan menimbulkan terjadinya kegagalan audit (Geiger dan Raghunandan, 2002) dan sering mengakibatkan tingginya tingkat risiko kecurangan yang akan terjadi (Corcelo dan Nagy, 2004). Oleh sebab itu, keadaan ini dapat mempengaruhi tingginya biaya audit agar auditor mendapatkan informasi yang lebih banyak tentang lingkungan bisnis klien (Moza, et.al., 2017). Oleh sebab itu biaya audit umumnya akan mencerminkan tingginya kualitas audit diberikan auditor (Goodwin-Stewart et al., 2006).

\subsection{Keahlian Akuntansi dan Keuangan CEO, Komit Audit dan Biaya Audit}

Pada bagian sebelumnya telah dikemukakan, keahlian akuntansi dan keuangan CEO dianggap berdampak positif pada peningkatan kualitas suatu laporan keuangan. Hal ini disebabkan keahlian 
akuntansi dan keuangan CEO berdampak pada pemahaman mereka terhadap pentingnya pengendalian intern yang dapat mempengaruhi risiko bisnis perusahaan. Dengan demikian, CEO berkeahlian akuntansi dan keuangan akan bertindak sangat hati-hati, sehingga membuat laporan keuangan lebih berkualitas. Peningkatan kualitas tersebut mencerminkan rendahnya salah saji laporan keuangan. Hal ini memberikan gambaran menurunnya risiko bisnis perusahaan. Dalam hubungannya dengan pemeriksaan terhadap laporan keuangan, risiko bisnis merupakan faktor penting dalam mempertimbangkan luasnya pemeriksaan yang akan dilakukan. Tingginya risiko bisnis akan mengakibatkan tingginya risiko audit yang akan dihadapi auditor serta berdampak pada tingginya biaya audit yang akan ditetapkan (Hay et.al, 2006). Bell et al., 2002 melaporkan dalam hasil penelitiannya bahwa konservatif berdampak pada rendahnya salah saji dalam laporan keuangan dan menekan tingkat risiko audit, sehingga berakibat pada rendahnya biaya audit yang ditetapkan. Kalelkar dan Khan (2016) mengemukakan bahwa keahlian akuntansi dan keuangan CEO memberikan dampak pada meningkatnya kepercayaan auditor terhadap laporan keuangan, menurunnya risiko audit, dan pada akhirnya menurunkan biaya audit yang ditetapkan.

Walaupun demikian, terdapat kemungkinan keahlian akuntansi dan keuangan akan dampak negatif terhadap perilaku CEO. CEO berkeahlian akuntansi dan keuangan akan bertindak lebih agresif dan lebih mampu dalam menerapkan praktik-praktik pengelolaan laba. Hal ini tentu saja akan berdampak pada kemungkinan menurunnya kualitas laporan keuangan dan berdampak pada biaya audit. Walaupun tidak secara jelas apakah terjadi pada perusahaan dengan anggota komite audit berkeahlian akuntansi dan keuangan, Johnson et al (2012) menemukan bahwa tingginya biaya audit sangat terkait dengan CEO yang narsis dan biaya audit yang tinggi sangat terkait dengan akrual diskresioner (Gul et al., 2003).

Keberlawanan terhadap hasil penelitian tersebut akan sangat menarik untuk dilakukan penelitian lebih lanjut tentang keterkaitan antara CEO yang mempunyai keahlian akuntansi dan keuangan dengan besarnya biaya audit. Menggunakan dasar pertimbangan bahwa CEO yang berkeahlian akuntansi dan keuangan akan menurunkan risiko bisnis dan mampu membuat laporan keuangan lebih berkualitas, sehingga akan menurunkan biaya audit. Oleh sebab itu, hipotesis yang diteliti pada penelitian ini adalah :

\section{H1. CEO dengan keahlian akuntansi dan keuangan akan menurunkan biaya audit.}

Kehadiran komite dalam suatu perusahaan telah memberikan kontroversi dalam hubungannya dengan auditor eksternal, khususnya berhubungan dengan biaya audit. Dikemukakan oleh Abbott et.al (2003), terdapat beberapa tindakan yang akan dilakukan komite audit berkaitan eksternal auditor, yaitu menyarankan kepada manajemen untuk diaudit oleh auditor bereputasi tinggi, meminta kepada auditor 
untuk memperluas lingkup audit, dan secara tidak langsung mempengaruhi luasnya lingkup audit dengan mengurangi ancaman manajeman untuk mengganti auditor. Ketiga tindakan tersebut secara umum akan berpengaruh terhadap tingginya biaya audit.

Pada sisi lain, kehadiran komite audit berkeahlian akuntansi dan keuangan diharapkan mampu meningkatkan efektivitas dari pengendalian internal sehingga diharapkan akan mampu menekan terjadinya kecurangan. Hal ini akan berakibat pada kemampuan komite audit membantu auditor mengurangi tingkat risiko yang akan dihadapi sehingga akan menekan biaya audit (Collier dan Gregory, 1996). Hasil berbeda ditemukan Goodwin dan Munro (2004) bahwa auditor percaya bahwa kehadiran komite audit akan memberikan dampak kecil pada pengujian audit, dan akan berakibat pada biaya audit lebih besar. Hal ini sebagai akibat meningkatnya jumlah waktu akibat adanya hubungan kemitraan dengan manajer. Pada sisi lain, Goodwin-Stewart dan Kent (2006) mengemukakan dalam hasil penelitiannya bahwa kehadiran komite audit menuntut kualitas audit yang semakin tinggi, dan pada akhirnya meningkatkan biaya audit yang akan dibayarkan.

Kontroversi yang terjadi tentang keterkaitan komite audit dengan biaya audit, akan menarik untuk dilakukan penelitian lebih lanjut. Dengan tingkat keyakinan komite audit berkeahlian akuntansi dan keuangan mampu membantu meningkatkan pengendalian intern yang ada, maka keberadaan komite audit akan menurunkan biaya audit. Atas dasar pertimbangan di atas, penelitian ini mencoba untuk menguji keterkaitan keduanya dengan hipotesis yang diajukan adalah :

H2. Keberadaan komite audit berkeahlian akuntansi dan keuangan akan mempengaruhi biaya audit.

Konsisten dengan dasar pertimbangan kedua hipotesis sebelumnya dan menggunakan dasar pertimbangan bahwa keberadaan komite audit dapat membantu manajemen melakukan pemantauan pelaksanaan pengendalian yang diterapkan dan bertanggung jawab terhadap proses pelaporan keuangan. Untuk itu, hipotesis ketiga yang diajukan pada penelitian ini adalah :

H3. Komite audit yang berkeahlian akuntansi dan keuangan mampu membantu CEO menekan biaya audit yang akan dibayarkan.

\section{Metode Penelitian}

\subsection{Data dan Sampel Penelitian}

Penelitian ini menggunakan data sekunder yang berhubungan dengan data biaya audit, CEO, anggota komite audit, serta data keuangan perusahaan manufaktur di Pasar Modal Indonesia. Rentang pengamatan dilakukan dari tahun 2010 hingga tahun 2016, sehingga populasi yang digunakan adalah perusahaan manufaktur yang telah terdaftar hingga tahun 2009. 
Seleksi sampel didasarkan pada kriteria-kriteria tertentu (Sekaran dan Bougie, 2016). Adapun kriteria-kriteria yang digunakan, yaitu :

a. Perusahaan sampel menggunakan mata uang rupiah secara konsisten.

b. Data terkait dengan variabel penelitian disajikan secara lengkap.

Berdasarkan kriteria tersebut, banyaknya perusahaan sampel atau jumlah pengamatan (observasi) tersaji pada Tabel 1 berikut ini :

Tabel 1

Hasil Seleksi Sampel

\begin{tabular}{|c|c|}
\hline Perusahaan sektor manufaktur yang terdaftar di Bursa Efek Indonesia sampai dengan 2009 & 96 \\
Dikurangi : & $(6)$ \\
- Penggunaan mata uang rupiah tidak secara konsisten & $(15)$ \\
\hline - Tidak secara lengkap menyajikan data yang diperlukan (termasuk informasi biaya audit) & 75 \\
\hline Jumlah Perusahaan Sampel & 7 \\
\hline Masa Pengamatan & 525 \\
\hline Jumlah Observasi & \\
\hline
\end{tabular}

Sumber : Data yang diolah

\subsection{Definisi Variabel dan Pengukurannya}

Penelitian ini menggunakan variabel dependen biaya audit (AFEE), yang menunjukkan jumlah biaya audit untuk masa perikatan tertentu. Oleh sebab itu, AFEE diukur dari logaritma natural biaya audit (auditfee).

Di samping itu juga, untuk variabel independen menggunakan CEO berkeahlian akuntansi dan keuangan. Mengikuti Custodio dan Metzger (2014), CEO berkeahlian akuntansi dan keuangan didefinisikan sebagai CEO berlatar belakang pendidikan dan/atau berpengalaman dalam bidang keuangan, akuntansi, perbankan, investasi, dan kantor akuntan. Variabel ini bersifat dummy yang diberi nilai 1 apabila CEO berkeahlian dalam bidang keuangan dan akuntansi.

Selain itu juga, penelitian ini menggunakan variabel moderasi komite audit yang berkeahlian akuntansi dan keuangan. Mengikuti Badolato et al (2014), komite audit berkeahlian akuntansi dan keuangan didefiniskan sebagai seseorang yang berpendidikan akuntansi, keuangan, dan/atau berpengalaman dibidang akuntansi, audit, serta mengawasi penyusunan laporan keuangan. Untuk itu, ukuran yang digunakan adalah perbandingan banyaknya anggota berkeahlian akuntansi dan keuangan dengan seluruh anggota komite audit. 
Untuk melengkapi variabel yang digunakan, terdapat beberapa variabel kontrol yang diprediksi akan ikut mempengaruhi biaya audit. Diikut sertakannya variabel kontrol didasarkan pertimbangan, bahwa perusahaan yang lebih besar, dan lebih beresiko umumnya berkaitan dengan biaya audit yang semakin besar (Simunic, 1980; Francis, 1984). Perusahaan yang lebih besar umumnya diindikasikan dengan tingginya total nilai aset atau total penjualan (pendapatan), sedangkan perusahaan yang lebih berisiko diindikasikan mempunyai tingkat utang yang tinggi, serta berkaitan dengan probilitas yang rendah (Hay, Knechel, dan Wong, 2006). Mengikuti Fuby dkk (2017), beberapa variabel kontrol yang digunakan adalah :

1. SIZE, adalah logaritma natural total aset perusahaan $i$ di tahun $t$.

2. ROA, adalah perbandingan laba bersih dengan total aset Perusahaan $i$ di tahun $t$.

3. DEBT, adalah perbandingan utang jangka panjang dengan total aset Perusahaan $i$ di tahun $t$.

4. CURRENT, adalah perbandingan aset lancar dengan total aset perusahaan $i$ di tahun $t$.

5. QUICK, adalah perbandingan aset lancar (setelah dikurangi dengan persediaan) dengan total utang lancar perusahaan $i$ di tahun $t$.

Ukuran perusahaan yang besar (SIZE) maupun perusahaan dengan risiko yang besar (DEBT, CURRENT, dan QUICK) diduga meningkatan biaya audit, sedangkan ROA diduga meningkatkan biaya audit (Hay, et.al., 2006).

\subsection{Model Penelitian}

Untuk menguji ketiga hipotesis yang telah diajukan, penelitian ini menggunakan metode regresi berganda. Hipotesis pertama dan kedua pada penelitian bertujuan untuk menguji bahwa CEO dan komite audit berkeahlian akuntansi dan keuangan akan menurunkan biaya audit. Untuk kegunaan menguji hipotesis pertama dan kedua, model persamaan regresi yang digunakan adalah :

$$
\begin{aligned}
\mathrm{AFEE}_{\mathrm{i}, \mathrm{t}}= & \alpha_{1}+\beta_{1} \mathrm{CEO}_{\mathrm{i}, \mathrm{t}}+\beta_{2} \mathrm{KA}_{\mathrm{i}, \mathrm{t}}+\beta_{3} \mathrm{SIZE}_{\mathrm{i}, \mathrm{t}}+\beta_{4} \mathrm{ROA}_{\mathrm{i}, \mathrm{t}}+\beta_{5} \mathrm{DEBT}_{\mathrm{i}, \mathrm{t}}+\beta_{6} \mathrm{CURRENT}_{\mathrm{i}, \mathrm{t}} \\
& +\beta_{7} \mathrm{QUICK}_{\mathrm{i}, \mathrm{t}}++\varepsilon_{\mathrm{i}, \mathrm{t}} \quad \ldots \ldots \ldots \ldots \ldots \ldots \ldots \ldots \ldots \ldots \ldots \ldots \ldots \ldots \ldots \ldots \ldots \ldots \ldots \ldots \ldots \ldots \ldots \ldots \ldots \ldots \ldots \ldots \ldots \ldots \ldots \ldots \ldots \ldots \ldots \ldots \ldots \ldots \ldots \ldots \ldots
\end{aligned}
$$

Hipotesis ketiga bertujuan untuk menguji komite audit berkeahlian akuntansi dan keuangan mampu membantu CEO dalam menekan biaya audit. Oleh sebab itu, model persamaan regresi bagi kepentingan pengujian hipotesis ketiga adalah :

$$
\begin{aligned}
\mathrm{AFEE}_{\mathrm{i}, \mathrm{t}}= & \alpha_{1}+\beta_{1} \mathrm{CEO}_{\mathrm{i}, \mathrm{t}}+\beta_{2} \mathrm{KA}_{\mathrm{i}, \mathrm{t}}+\beta_{3} \mathrm{CEO}^{*} \mathrm{KA}_{\mathrm{i}, \mathrm{t}}+\beta_{4} \mathrm{SIZE}_{\mathrm{i}, \mathrm{t}}+\beta_{5} \mathrm{ROA}_{\mathrm{i}, \mathrm{t}} \\
& +\beta_{6} \mathrm{DEBT}_{\mathrm{i}, \mathrm{t}}+\beta_{7} \mathrm{CURRENT}_{\mathrm{i}, \mathrm{t}}+\beta_{8} \mathrm{QUICK}_{\mathrm{i}, \mathrm{t}}+\varepsilon_{\mathrm{i}, \mathrm{t}} \quad \ldots \ldots
\end{aligned}
$$




\section{Hasil Penelitian}

\subsection{Statistik Deskriptif}

Berdasarkan hasil pengolahan data yang telah dilakukan, hasil statistik deskriptif untuk keseluruhan variabel yang digunakan pada penelitian ini tersaji pada Tabel 2 berikut ini :

Tabel 2

Statistik Deskriptif

\begin{tabular}{|c|c|c|c|c|c|}
\hline \multicolumn{6}{|c|}{ Panel A } \\
\hline Variabel & $\mathbf{N}$ & Minimum & Maximum & Mean & Std. Deviation \\
\hline AFEE & 525 & $43,415,000$ & $15,090,000,000$ & $1,940,624,229$ & $2,255,578,615$ \\
\hline KA & 525 & 0.0000 & 1.0000 & 0.6618 & 0.2748 \\
\hline SIZE & 525 & $161,975,700,000$ & $15,346,145,677,737$ & $8,488,805,153,680$ & $2,056,106,498,266$ \\
\hline ROA & 525 & -2.2700 & 0.6800 & 0.2521 & 0.1828 \\
\hline DEBT & 525 & 0.0445 & 0.6605 & 0.4162 & 0.3307 \\
\hline CURRENT & 525 & 0.0000 & 0.8098 & 0.6912 & 0.2424 \\
\hline QUICK & 525 & 0.0000 & 2.6207 & 2.4678 & 5.8212 \\
\hline \multicolumn{6}{|c|}{ Panel B } \\
\hline \multicolumn{3}{|c|}{ Tahun } & \multicolumn{2}{|c|}{$\begin{array}{l}\text { Jumlah CEO Berkeahlian } \\
\text { Akuntansi dan Keuangan }\end{array}$} & Persentase \\
\hline \multicolumn{3}{|c|}{2010} & \multicolumn{2}{|c|}{17} & 0.23 \\
\hline \multicolumn{3}{|c|}{2011} & \multicolumn{2}{|c|}{17} & 0.23 \\
\hline \multicolumn{3}{|c|}{2012} & \multicolumn{2}{|c|}{16} & 0.21 \\
\hline \multicolumn{3}{|c|}{2013} & \multicolumn{2}{|c|}{18} & 0.24 \\
\hline \multicolumn{3}{|c|}{2014} & \multicolumn{2}{|c|}{19} & 0.25 \\
\hline \multicolumn{3}{|c|}{2015} & \multicolumn{2}{|c|}{19} & 0.25 \\
\hline \multicolumn{3}{|c|}{2016} & \multicolumn{2}{|c|}{22} & 0.29 \\
\hline \multicolumn{3}{|c|}{ Total } & \multicolumn{2}{|c|}{128} & 0,24 \\
\hline
\end{tabular}

Sumber : Output SPSS

Pada panel A (Tabel 2), menyajikan melaporkan hasil statistik deskriptif untuk seluruh variabel penelitian yang digunakan pada penelitian ini. Pada Panel A dilaporkan bahwa nilai rata-rata biaya audit (AFEE) yang dibayarkan sebesar 1,9 milyar jauh dibawah nilai tertinggi (15 milyar). Hal ini menyiratkan hanya beberapa perusahaan sampel saja yang membayarkan biaya audit tinggi. Pembayaran biaya audit yang tinggi ini, terjadi pada perusahaan yang mempunyai kompleksitas bisnis yang tinggi dan diaudit oleh KAP yang berafiliasi dengan kantor akuntan BIG4. Tingkat rerata anggota komite audit (KA) sebesar 
0,67 mendekati nilai maksimum sebesar 1 . Kondisi ni menggambarkan anggota komite audit pada perusahaan sampel rata-rata memiliki keahlian akuntansi dan keuangan. Tingkat rerata total aset sebesar 8,4 triliun mendekati nilai tertinggi sebesar 15 triliun. Rerata nilai ROA (0.2521), DEBT (0.4162), CURRENT (0.6605), dan QUICK (2.4678) mendekati nilai tertinggi (masing-masing sebesar 0.6800, 0.6605, 0.8098, dan 2.6207).

Panel B menyajikan statistik deskriptif dari variabel CEO yang diukur dengan menggunakan dummy keahlian akuntansi dan keuangan CEO. Dari seluruh pengamatan (525), terdapat 128 pengamatan (24\% ) yang terindikasi menggunakan CEO berkeahlian akuntansi dan keuangan. Secara rinci disajikan pada Panel B, dari 75 perusahaan sampel terdapat 16 hingga 22 perusahaan atau berkisar antara $21 \%$ $24 \%$. Walaupun jumlah perusahaan yang menggunakan CEO berkeahlian akuntansi dan keuangan dapat dikatakan kecil, tetapi telah terjadi peningkatan penggunaan CEO berkeahlian akuntansi dan keuangan disetiap tahunnya.

\subsection{Hasil Pengujian Hipotesis}

\subsubsection{Pengujian Hipotesis Pertama dan Kedua}

Seperti telah dikemukan pada bagian sebelumnya, hipotesis 1 dan 2 dimaksudkan untuk melakukan pengujian bahwa CEO dan KA (Komite Audit) dengan keahlian akuntansi dan keuangan akan menurunkan biaya audit. Tabel 3 berikut ini, menyajikan hasil pengolahan data dari pengujian hipotesis 1 dan 2 :

Tabel 3

Hasil Pengujian Hipotesis 1 dan 2 $\mathrm{AFEE}_{\mathrm{i}, \mathrm{t}}=\alpha_{1}+\beta_{1} \mathrm{CEO}_{\mathrm{i}, \mathrm{t}}+\beta_{2} \mathrm{KA}_{\mathrm{i}, \mathrm{t}}+\beta_{3} \mathrm{SIZE}_{\mathrm{i}, \mathrm{t}}+\beta_{4} \mathrm{ROA}_{\mathrm{i}, \mathrm{t}}+\beta_{5} \mathrm{DEBT}_{\mathrm{i}, \mathrm{t}}$ $+\beta_{6}$ CURRENT $_{\mathrm{i}, \mathrm{t}}+\beta_{7} \mathrm{QUICK}_{\mathrm{i}, \mathrm{t}}++\varepsilon_{\mathrm{i}, \mathrm{t}}$

\begin{tabular}{|l|c|c|c|c|}
\hline & \multirow{2}{*}{$\begin{array}{c}\text { Prediksi } \\
\text { Tanda }\end{array}$} & \multicolumn{3}{|c|}{ AFEE } \\
\cline { 3 - 6 } & & Koefisien & t-hitung & Nilai-p \\
\hline CEO & - & -0.0317 & 3.2638 & $\left.0.0479^{* *}\right)$ \\
\hline KA & - & -0.0206 & 3.1117 & $\left.0.0491^{* *}\right)$ \\
\hline SIZE & + & 0.0272 & 2.2455 & $\left.0.0252^{* *}\right)$ \\
\hline ROA & - & -0.2235 & 4.2463 & $\left.0.0000^{*}\right)$ \\
\hline DEBT & + & 0.0538 & 2.3367 & $\left.0.0365^{* *}\right)$ \\
\hline CURRENT & + & 0.06422 & 3.0061 & $\left.0.0028^{*}\right)$ \\
\hline QUICK & + & 0.0113 & 2.2819 & $\left.0.0200^{* *}\right)$ \\
\hline $\begin{array}{l}*) \text { Tingkat 1\% } \\
* *) \text { Tingkat 5\% } \\
* * *) \text { Tingkat 10\% }\end{array}$ & & & \\
\hline
\end{tabular}

Sumber : Hasil olah data SPSS 
Tabel 3 di atas menunjukkan CEO yang berkeahlian akuntansi dan keuangan terhadap biaya audit (AFEE) mempunyai nilai-p (signifikansi) sebesar 0,0479 lebih kecil dari tingkat signifikansi 5\% $(\alpha=$ $0,05)$ dan mempunyai koefisien bernilai negatif $(-0,0317)$ sesuai arah yang telah diduga sebelumnya. Hasil ini menunjukkan bahwa secara signifikan (pada tingkat 5\%) CEO yang berkeahlian akuntansi dan keuangan mampu menekan biaya audit yang dibayarkan. Hasil ini mendukung hipotesis 1 yang diajukan dan menunjukkan konsistensi hasil yang telah didapat pada penelitian Kalekar dan Khan (2016).

Hal yang sama ditunjukkan pada hipotesis kedua bahwa komite audit (KA) yang berkeahlian akuntansi dan keuangan terhadap biaya audit (AFEE) diperoleh nilai-p (signifikansi) sebesar 0.0491 lebih rendah dari nilai alpha $(\alpha=0,05)$ dengah arah negatif $(-0,0317)$. Hasil ini memberikan informasi bahwa secara signifikan (pada tingkat 5\%) audit komite berkeahlian akuntansi dan keuangan mampu menekan biaya audit yang dibayarkan. Hasil ini menyiratkan dukungan terhadap hipotesis 2 yang telah diajukan dan konsistensi dengan hasil yang telah didapat sebelumnya pada penelitian Abbot et al (2003).

Untuk variabel control, seperti diduga sebelumnya, besarnya ukuran perusahaan (SIZE) maupun tingginya risiko perusahaan (DEBT, CURRENT, dan QUICK) meningkatkan besarnya biaya audit. Sebaliknya, besarnya tingkat profitabilitas (ROA) berdampak negatif terhadap biaya audit. Artinya ROA yang rendah akan meningkatkan biaya audit.

\subsubsection{Pengujian Hipotesis Ketiga}

Hipotesis ke-3 ditujukan untuk menguji bahwa audit komite yang berkeahlian akuntansi dan keuangan mampu membantu CEO dalam menekan biaya audit yang akan dibayarkan. Untuk menguji hipotesis ini, peneliti menggunakan variabel moderasi komite audit sebagai pemoderasi CEO. Hasil pengolahan data disajikan disajikan pada Tabel 4 berikut ini :

Tabel 4

Hasil Pengujian Hipotesis 3

$\mathrm{AFEE}_{i, t}=\alpha_{1}+\beta_{1} \mathrm{CEO}_{i, t}+\beta_{2} \mathrm{KA}_{i, t}+\beta_{3} \mathrm{CEO}^{*} \mathrm{KA}_{i, t}+\beta_{4} \mathrm{SIZE}_{i, t}+\beta_{5} \mathrm{ROA}_{i, t}+\beta_{6} \mathrm{DEBT}_{i, t}$ $+\beta_{7} \mathrm{CURRENT}_{i, t}+\beta_{8} \mathrm{QUICK}_{i, t}+\varepsilon_{i, t}$

\begin{tabular}{|l|c|c|c|c|}
\hline \multirow{2}{*}{} & \multirow{2}{*}{$\begin{array}{c}\text { Prediksi } \\
\text { Tanda }\end{array}$} & \multicolumn{3}{|c|}{ AFEE } \\
\cline { 3 - 6 } & & Koefisien & t-hitung & Nilai-p \\
\hline CEO & - & -0.0516 & 2.4531 & $\left.0.0147^{* *}\right)$ \\
\hline KA & - & -0.0466 & 3.7645 & $\left.0.0445^{* *}\right)$ \\
\hline CEO_KA & - & -0.0790 & 3.6392 & $\left.0.0102^{*}\right)$ \\
\hline SIZE & + & -0.0246 & 2.3013 & $\left.0.0447^{* *}\right)$ \\
\hline ROA & - & 0.2849 & 4.4195 & $\left.0.0000^{*}\right)$ \\
\hline DEBT & + & 0.0352 & 2.0214 & $\left.0.0983^{* *}\right)$ \\
\hline
\end{tabular}




\begin{tabular}{|c|c|c|c|c|}
\hline CURRENT & + & 0.0565 & 2.5798 & $0.0102 \quad *)$ \\
\hline QUICK & + & 0.0110 & 2.2451 & $0.0214 \quad * *)$ \\
\hline $\begin{array}{l}\text { *) Tingkat } 1 \% \\
* *) \text { Tingkat } 5 \% \\
* * *) \text { Tingkat } 10 \%\end{array}$ & & & & \\
\hline
\end{tabular}

Sumber : Output SPSS

Dari Tabel 4 di atas menunjukkan hasil yang tidak berbeda dengan hasil pengujian hipotesis 1 dan hipotesis 2. Variabel CEO tetap menunjukkan koefisien negatif dengan signifikansi (0.0147) lebih kecil dibandingkan dengan nilai $\alpha$ sebesar 5\%. Tidak berbeda dengan variabel CEO, pada pengujian hipotesis ketiga ini, nilai koefisien KA tetap bernilai negatif dengan nilai signifikansi sebesar 0.0445 lebih rendah dibandingkan tingkat signifikasi $(\alpha)$ sebesar 5\%. Hal yang menarik adalah koefisien yang ditunjukkan variabel moderasi (CEO_KA) juga bernilai koefisien negatif dan nilai signifikansinya (0.0102) lebih rendah dari tingkat signifikansi $(\alpha)$ sebesar 1\%. Hasil ini menyiratkan bahwa audit komite berkeahlian akuntansi dan keuangan mampu memoderasi kemampuan CEO dalam menekan biaya audit. Artinya, audit komite yang berkeahlian akuntansi dan keuangan mampu membantu CEO dalam menekan biaya audit. Secara keseluruhan, hasil ini mendukung hipotesis 3 yang telah diajukan.

Hasil lain yang ditunjukkan oleh ketiga pengujian diatas (Tabel 3, 4, dan 5) adalah keseluruhan variabel kontrol (SIZE, ROA, DEBT, CURRENT, dan QUICK) mempunyai nilai koefisien yang hampir menyerupai disetiap pengujiannya. Di samping itu juga, koefisien yang terdapat pada keseluruhan variabel kontrol di setiap pengujian menunjukkan arah yang sama dengan prediksi tanda yang telah diduga sebelumnya. Variabel SIZE, DEBT, CURRENT, dan QUICK menunjukkan koefisien bernilai positif, artinya biaya audit cenderung akan dibayarkan oleh perusahaan yang berukuran besar (SIZE) dan mempunyai risiko yang tinggi (DEBT, CURRENT, dan QUICK). Hal yang sama ditunjukkan oleh variabel kontrol ROA, nilai koefisien yang dihasilkan disetiap pengujian menunjukkan nilai negatif dan konsisten dengan dugaan sebelumnya. Kondisi ini memberikan makna bahwa perusahaan dengan tingkat ROA tinggi cenderung akan membayar biaya audit yang rendah.

\subsection{Diskusi}

Seperti telah dikemukakan pada hasil pengujian hipotesis 1 , hasil pengujian telah membuktikan bahwa CEO yang berkeahlian akuntansi dan keuangan mampu menekan biaya audit yang akan dibayarkan. Kehadiran CEO yang berkeahlian akuntansi dan keuangan dapat meningkatkan kepercayaan auditor terhadap kualitas laporan keuangan. Hal ini memberikan informasi bahwa kehadiran CEO dengan keahlian akuntansi dan keuangan dianggap lebih mampu memahami kebijakan-kebijakan akuntansi dan keuangan sehingga berdampak pada kemudahan mereka dalam melakukan proses penyajian laporan keuangan. Oleh sebab itu, hal ini akan memberikan dampak pada kehati-hatian perusahaan untuk 
menyampaikan laporan keuangan, sehingga kualitas laporan keuangan semakin meningkatnya. Tingginya kualitas laporan keuangan ini mencerminkan rendahnya tingkat salah saji yang terdapat laporan keuangan dan akan berdampak pada menurunnya tingkat risiko yang akan dihadapi. Bagi kepentingan audit, tingkat risiko merupakan faktor penting dalam menentukan kedalaman audit pada bagian-bagian yang akan menjadi fokus pemeriksaan. Semakin rendah tingkat risiko akan berdampak pada semakin sempitnya ruang lingkup pemeriksaan, sehingga akan dapat menekan biaya audit yang akan dibebankan.

Hasil pengujian hipotesis 2 dan 3 juga menunjukkan hasil yang mendukung hipotesis yang diajukan. Keberadaan audit komite dengan keahlian yang dimiliknya juga menunjukkan pengaruh yang bersifat negatif terhadap besarnya biaya audit yang akan dibayarkan. Hal ini memberikan makna bahwa kehadiran audit komite yang berkeahlian akuntansi dan keuangan juga mampu menekan biaya audit. Sama halnya dengan CEO, audit komite yang berkeahlian akuntansi dan keuangan juga mampu mempengaruhi tingginya tingkat kepercayaan auditor pada kualitas laporan keuangan. Audit komite akan lebih mudah melakukan pemahaman terhadap pengendalian intern perusahaan dan melakukan pengawasan terhadap efektifitas pengendalian intern. Kehadiran audit komite yang berkeahlian akuntansi dan keuangan akan lebih mudah memantau kemungkinan terjadinya kelememahan-kelemahan pengendalian intern dan segera mengambil tindakan untuk melakukan perbaikan-perbaikan yang diperlukan. Kondisi ini akan berdampak pada menurunkan kemungkinan terjadinya kecurangan, sehingga kualitas laporan keuangan akan meningkat. Oleh sebab itu, kehadiran komite audit berkeahlian akuntansi dan keuangan akan berdampak pada risiko audit yang akan dihadapi auditor dan menurunnya biaya audit yang akan dibayarkan. Dan dengan demikian, komite audit dapat membantu CEO dalam menekan biaya audit.

\section{Kesimpulan, Implikasi dan Keterbatasan}

\subsection{Kesimpulan}

Penelitian ini melakukan pengujian terhadap (1) CEO dengan keahlian akuntansi dan keuangan akan menurunkan biaya audit. (2) komite audit berkeahlian kuntansi dan keuangan akan menurunkan biaya audit yang akan dibayarkan, dan (3) audit komite yang berkeahlian akuntansi dan keuangan mampu membantu CEO dalam menurunkan biaya audit yang akan dibayarkan. Dari pengujian yang telah dilakukan, ditemukan bahwa (1) CEO yang berkeahlian akuntansi dan keuangan mampu menurunkan biaya audit yang akan dibayarkan, (2) komite audit berkeahlian akuntansi dan keuangan mampu menurunkan biaya audit yang akan dibayarkan, dan (3) komite audit mampu membantu CEO dalam menurunkan biaya audit yang dibayarkan.

ISSN : 1693-0164 | e-ISSN : 2581-074X 


\subsection{Implikasi}

Informasi yang diperoleh dari penelitian ini adalah CEO dan audit komite dengan keahliannya dalam bidang akuntansi dan keuangan memberikan dampak terhadap menurunnya biaya audit yang dibayarkan. Meskipun keberhasilan suatu perusahaan bukanlah hanya didasarkan pada keahlian akuntansi dan keuangan, akan tetapi hasil ini dapat menjadi dasar pertimbangan perusahaan untuk memilih CEO yang berkeahlian akuntansi dan keuangan. CEO dengan keahlian akuntansi dan keuangan dianggap lebih mudah memahami tingkat risiko bisnis yang akan dihadapi perusahaan. Hal serupa ditujukan dalam menentukan anggota audit komite berkeahlian akuntansi dan keuangan, karena diharapkan akan dapat lebih mudah membantu CEO dalam melakukan pengawasan terhadap alat-alat pengendalian yang ada.

\subsection{Keterbatasan}

Penelitian ini mempunyai keterbatasan pada sampel penelitian yang hanya terbatas pada sektor manufaktur, sehingga dapat mempengaruhi generalisasi hasil penelitian. Untuk itu, bagi kepentingan riset selanjutnya disarankan untuk memperluas sektor industri. Penelitian ini juga tidak menggunakan keberadaan audit internal di dalam perusahaan yang juga secara operasional ikut serta dalam mengawasi jalannya operasi perusahaan. Bagi kepentingan penelitian selanjutnya, disarankan untuk menggunakan audit internal sebagai variabel penelitian.

\section{DAFTAR PUSTAKA}

Abbort, Lawrence. J., Susan Parker, Gary F. Peters, dan K. Raghunandan. 2003. The Association between Audit Committee Characteristics and Audit Fees. Auditing: A Journal Of Practice \& Theory. Vol. $22(2): 17-32$

Abbott, L. J., S. Parker, dan G. F. Peters, 2004, Audit Committee Characteristics And Restatements, Auditing: A Journal of Practice and Theory. $23: 69-87$.

Agrawal, A., dan S. Chadha. 2005. Corporate Governance And Accounting Scandals. Journal of Law and Economics. Vol 48 (2) : 371-406.

Bhagat, S., Bolton, B., \& Subramanian, A. 2010. CEO Education , CEO Turnover , and Firm Performance CEO Education, CEO Turnover, and Firm Performance. Journal of Applied Management and Entrepreneurship, 13(2), 26.

Beasley, M.S., Carcello, J.V., Hermanson, D.R., Neal, T.L. 2009. TheAudit Committee Oversight Process. Contemporary Accounting Research. Vol 26 : 65-122.

Bell, T., W. Landsman, and D. Shackelford. 2002. Auditors' Perceived Business Risk And Audit Fees: Analysis And Evidence. Journal of Accounting Research 39: 35-43.

Boyd, D. E., R. Chandy, and M. Cunha, Jr. 2010. When Do Chief Marketing Officers Impact Value? A Customer Power Explanation. Journal of Marketing Research 47: 1162-1176. 
Badolato P.G, D.C Danelson, Matthew Ege. 2014. Audit Committee Financial Expertise And Earnings Management: Therole of status, Journal of Accounting and Economics. No. 58 : 208-230.

Carcello, J.V. dan Nagy, A.L. 2004. Audit Firm Tenure and Fraudulent Financial Reporting. Auditing: A Journal of Practice and Theory, Vol. 23 (2) : 55-69.

Cao, Z., dan G. Narayanamoorthy. 2014. Accounting and litigation risk: Evidence from directors' and officers' insurance pricing. Review of Accounting Studies 19 (1): 1-42.

Custodio, C., dan D. Metzger. 2014. Financial Expert CEO's : CEO's Work Experience and Firm's Financial Policies. Journal of Financial Economics 114 (1): 125-154.

Coff, R. W. 2002. Human Capital, Shared Expertise, And The Likelihood Of Impasse In Corporate Acquisitions. Journal of Management 28: 107-128.

Collier, P., and A. Gregory, 1996, Audit Committee Effectiveness And The Audit Fee, European Accounting Review 5 : 177-198.

Dhaliwal, Dan., Vic Naiker, dan Farshid Navissi. 2010. TheAssociation Between Accruals Quality and the Characteristics of Accounting Experts and Mix of Expertise on Audit Committees. Contemporary Accounting Research. Vol. 27 (3) : 787-827

Fama, E.F., Jensen, M.C. 1983. Separation of Ownership And Control. Journal of Law and Economics, $26: 301-325$.

Francis, J. R. 1984. The Effect Of Audit Firm Size On Audit Prices: AStudy Of The Australian Market. Journal of Accounting \& Economics, 6: 133-151.

Fuby Fridaini, Puspita Anggraeni, Edi Sukarmanto. 2017. Audit Partner Rotation Meningkatkan Audit Fee ?. Artikel disajikan dalam Simposium Ilmiah Akuntansi I, IAI - KAPD Sumatera Utara.

Geiger, M.A. and Raghunandan, K. 2002. Auditor Tenure and Audit Reporting Failures. Auditing: A Journal of Practice and Theory, Vol. 21 (1) : 67-78.

Goodwin-Stewart, Jenny., Pamela Kent. 2006. Relation Between External Audit Fees, Audit Committee Characteristics and Internal Audit. Journal of Accounting and Finance, No. $46: 387-404$.

Goodwin, J., dan L. Munro, 2004, TheImpact Of Audit Committee Meeting Frequency On The External Audit: Perceptions Of Australian Auditors, working paper (Queensland University of Technology, Brisbane, Qld).

Gul, F. A., C. J. Chen, dan J. S. Tsui. 2003. Discretionary Accounting Accruals, Managers' Incentives, and Audit Fees. Contemporary Accounting Research 20 (3): 441-464.

Hannan, M. T., dan J. Freeman. 1977. ThePopulation Ecology of Organizations. American Journal of Sociology 82 (5) : 929-964.

ISSN : 1693-0164 | e-ISSN : 2581-074X 
Hay, D. C., W. R. Knechel, dan N. Wong. 2006. Audit Fees: A Meta-Analysis of The Effect Of Supply And Demand Attributes. Contemporary Accounting Research, 23 (1): 141-191.

Hayes, R. M., dan S. Schaefer. 2000. Implicit Contracts And The Explanatory Power Of Top Executive Compensation For Future Performance. The RAND Journal of Economics 31 (2): 273-293.

Johnson, E. N., J. R. Kuhn, Jr., B. A. Apostolou, dan J. M. Hassell. 2012. Auditor Perceptions of Client Narcissism As A Fraud Attitude Risk Factor. Auditing: A Journal of Practice \& Theory Vol 32 (1): 203-219.

Kalelkar, Rachana., dan Sarfraz Khan. 2016. CEO Financial Background and Audit Pricing. Accounting Horizons Vol 30 (3) : 325-339.

Koyuncu, B., S. Firfiray, B. Claes, dan M. Hamori. 2010. CEO's With A Functional Background In Operations: Reviewing Their Performance and Prevalence In The Top Post. Human Resource Management 49: 869-882.

Krishnan, J., 2005. Audit Committee Quality And Internal Control : An Empirical Analysis. Accounting Review. Vol. 80 (2) : 649-675.

Krishnan, Gopal V., Gnanakumar Visvanathan. 2008. Does the SOX Definition of an Accounting Expert Matter ? TheAssociation between Audit Committee Directors' Accounting Expertise and Accounting Conservatism, Contemporary Accounting Research. Vol. 25 (3) : 827-57.

Moza Audina Sopharia, Puspita Anggraeni, dan Edi Sukarmanto. (2017). Asimetri Informasi sebagai Pemoderasi Pengaruh Audit Tenure terhadap Volatilitas Idiosinkratik Return Saham, Artikel disajikan dalam Simposium Nasional Akuntansi XX, Jember.

Otoritas Jasa Keuangan. 2015. Peraturan Otoritas Jasa Keuangan No. 55/POJK.04/2015 Tentang Pembentukan dan Pedoman Pelaksanaan Kerja Komite Audit.

Simunic, D. A. 1980. ThePricing of Audit Services: Theory And Evidence. Journal of Accounting Research, 18 (2): 161-190. 